\title{
The structural relationship of meaning in life, personal growth initiative, life orientation and wisdom with authentic personality in students
}

\author{
Farzad Ghaderi $^{1}$, Koroush Namdari ${ }^{2}$, Shabrooz Ghobadi ${ }^{3}$, Mozhgan Shokroolahi ${ }^{4}$ \\ 1-Ph.D student of Psychology, Department of Psychology, Faculty of Education and Psychology, University of \\ Isfahan, Isfahan, Iran (Corresponding Author). E-mail: Ghaderi68@yahoo.com \\ 2- Assistance Professor, Department of Psychology, Faculty of Education and Psychology, University of Isfahan, \\ Isfahan, Iran. \\ 3- Masters of Counseling, University of Isfahan, Isfahan, Iran. \\ 4- Ph.D student of Psychology, Department of Psychology, Faculty of Educational Sciences and Psychology, Shahid \\ Chamran University of Ahvaz, Ahvaz, Iran.
}

Received: 04/07/2019

Accepted: 15/10/2019

\begin{abstract}
Introduction: Personality and related structures have been considered as one of the fields of study in psychology and psychiatry.

Aim: The purpose of this study was to investigate structural relationships of Meaning in life, Personal Growth Initiative, Life orientation and wisdom with authentic personality in college students.

Method: In a hypothetical structural model of relationships between research variables, 166 students ( 85 boys and 81 girls) of University of Isfahan were selected by available sampling. They were evaluated with Meaning in Life, Life Orientation (Scheier and Carver, 1985), Personal Growth Initiative (Robitschek, 1998), Three-Dimensional Wisdom (Ardelt, 2003) and Authenticity personality Scales (Wood et al, 2008).

Results: The results showed that there is a positive and significant relationship between life orientation, meaning in life, Personal Growth Initiative and wisdom with authentic personality in students. The results of structural equation modeling also showed that optimism, Personal Growth Initiative and wisdom have a significant relationship with authentic personality of students. The evaluation of hypothetical model with fit indexes demonstrated that the hypothetical model fits the measurement model. The results showed a significant correlation between the orientation of life, Personal Growth Initiative, the authentic personality and meaning in life.
\end{abstract}

Conclusion: The findings of the present study, in addition to practical implications, has provide a useful framework for identifying the components that affect the formation and development of authentic personality in students.

Keywords: Meaning in life, Personal growth initiative, Life orientation, Wisdom, Authentic personality

How to cite this article : Ghaderi F, Ghobadi Sh, Namdari K, Shokroolahi M. The structural relationship of meaning in life, personal growth initiative, life orientation and wisdom with authentic personality in students. Shenakht Journal of Psychology and Psychiatry. $2019 ; 6$ (5): 55-71 . URL: http://shenakht.muk.ac.ir/article-1-578-fa.pdf

Copyright @ 92018 the Author (s). Published by Kurdistan University of Medical Sciences. This is an open access article distributed under the terms of the Creative Commons Attribution-Non Commercial License 4.0 (CCBY-NC), where it is permissible to download, share, remix, transform, and buildup the work provided it is properly cited. The work cannot be used commercially without permission from the journal. 


\title{
روابط ساختارى معنا در زندكى، اقدام براى رشد شخصى، جهت و خرد با اصالت شخصيت دانشجويان
}

\author{
فرزاد قادرى'، كورش نامدارى'، شبروز قبادى'، مز كان شكرالهى \\ ا.دانشجوى د كترى روان شناسى، گروه روان شناسى، دانشكده روان شناسى و علوم تربيتى، دانشكاه اصفهان، اصفهان، ايران (مولف مسئول). \\ ايميل:yahoo.com \\ r. استاديار، گروه روان شناسى، دانشكده روان شناسى و علوم تربيتى، دانشخاه اصفهان، اصفهان، ايران. \\ r. كارشناس ارشد مشاوره، دانشخاه اصفهان، اصفهان، ايران.

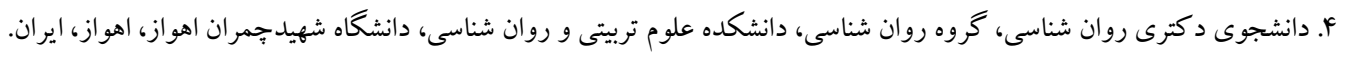

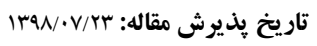 \\ تاريخ دريافت مقاله: r/
}

\section{جكيده}

مقدمه: شخصيت و سازهاى مرتبط با آن همواره بهعنوان يكى از زمينههاى مطالعاتى حوزه روانشناسى و روانيزشكى مطرح بوده

هدف: يُزوهش حاضر باهدف بررسى روابط ساختارى معنا در زندگى، رشد شخصى، جهت گيرى زندگى و خرد با اصالت شخصيت

انجام شد.

روش: با طرح يكك مدل ساختارى فرضى از روابط بين متغير هاى يزوهش، تعداد 199 نفر از دانشجويان دانشكاه اصفهان (ه人 نفر يسر

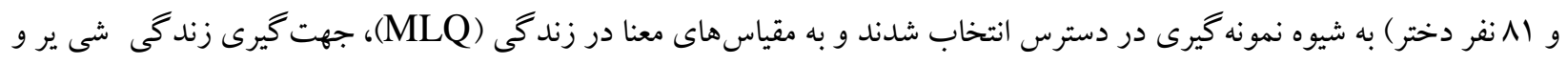

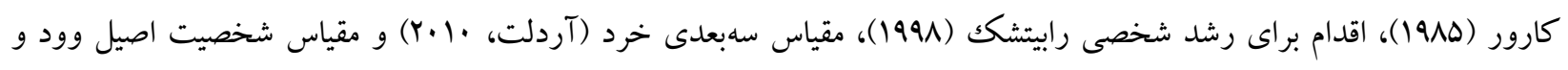

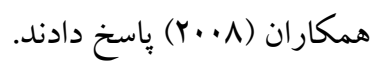

يافته ها: نتايج يزوهش نشان داد بين مؤلفهاى جهت گيرى زندگى، معنا در زندگى، رشد شخصى و خرد با اصالت شخصيت در دانشجويان رابطه مثبت و معنىدارى وجود دارد. نتايج مدل يابى معادلات ساختارى نيز نشان داد كه خوشبينى، اقدام براى رشد

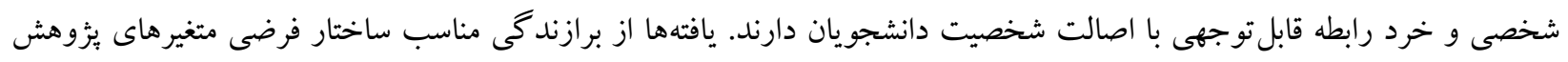

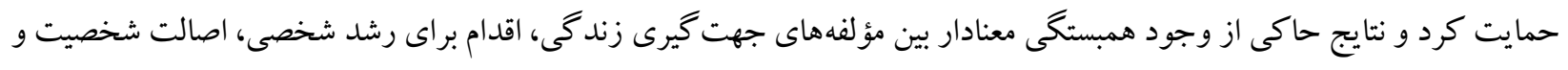
معنا در زندگى بود. نتيجه كيرى: يزوهش حاضر علاوه بر تلويحات كاربردى، جارجوب مفيدى را در رابطه با شناسايى مؤلفهاى بيش بينى كننده كسب و رشد اصالت شخصيت در دانشجويان فراهم مى كند.

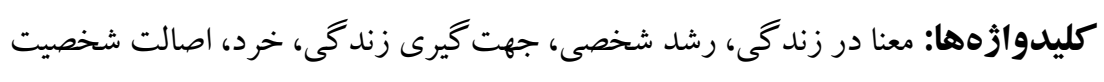




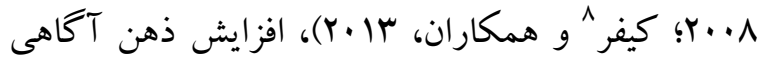

مقدمه

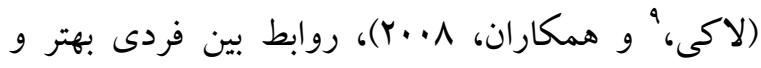

اصالت' كه به معناى پذيّرش خود واقعى و خودحقيقى

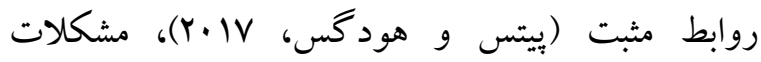

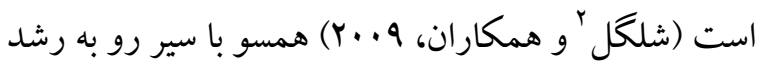
اجتماعى، هيجانى و رفتارى كمتر (كولدنر و برنشتين

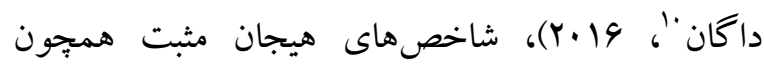
لذت، رضايت، خشنودى و خرسندى، قناعت، آرامش،

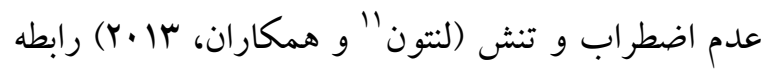
دارد. سطوح بالاى اصالت همجنين بيشبينى كننده هدف در زندگى،، لذت، علاقهمندى، عزت نفس و بذيرش مثبت خود و معناى زندگى هست (لنتون و همكاران، 19 (Y).

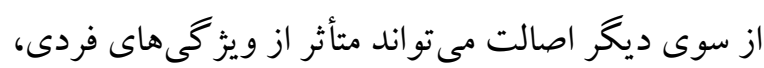

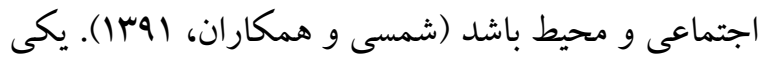
از سازههاى فردى كه اخيراً و همسو با جنبش روانشناسى وحسى باست مثبت مطرحشده است، معنا در زندكى "ا هست كه به احساسى از يكֶارجّى وجودى اشاره مى كند كه به دنبال

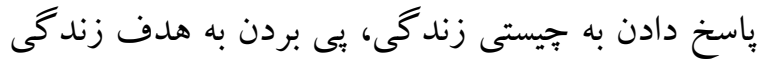
و دست يافتن به اهداف ارزنده و درنتيجه رسيدن به حس كامل بودن و مفيد بودن است (عليلو و خسروشاهى،

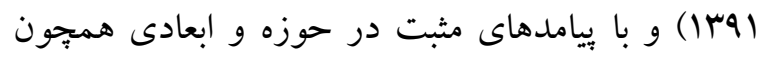

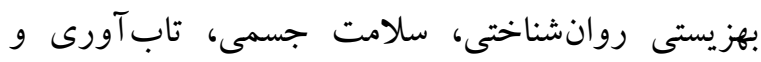

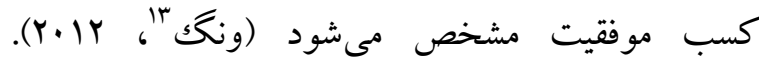
كراوس اين سازه را شامل F Y.IV ارزشى، حس هدفمندى، داشتن هدف و توانايى

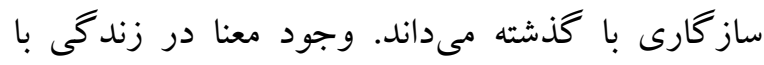
روانشناسى مثبت، در بسيارى از ديدگاههاى روانشناسى و مشاوره، يكى از اساسىترين جنبههاى زندكى سالم در

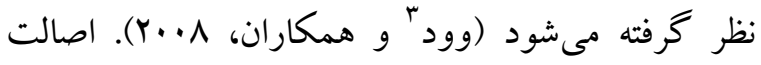
بهعنوان رفتار همخوان با افكار، احساسات و ارزشهاى فرد تعريفشده است و به اين معناست كه فرد به ديخران اجازه مىدهد كه جنبههاى واقعى خوب و بد آنها را

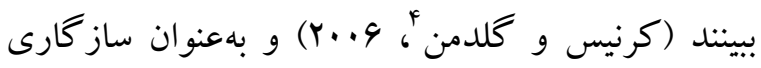
بين سه سطح؛ تجربه اوليه شخص، آگاهى و رفتار و ارتباطات بيرونى مطرحشده است. افراد داراى شخصيت اصيل ازخودبيكانكى بايينى دارند؛ بدين معنى كه داراى هويت بسيار باثباتى هستند كه دقيقاً با واقعيت منطبق است، همجنين زندگى اصيل بالايى دارند؛ بدين معنى كه بهصورت باثباتى بر مبناى اين ساختار هويت خود عمل

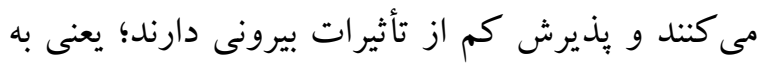
نيروهاى بيرونى هنگامى كه در تضاد با عقايد شخصى لئى آنها هستند، اجازه نمىدهند كه ادراكات و رفتارهاى اصيل گونه آنها را تغيير دهند (مالت بى هـ و همكاران، $(r \cdot) r$ نتايج مطالعات حاكى از آن است كه سطوح بالاى اصالت با رضايت از زندگى (كلدمن و كرنيس،

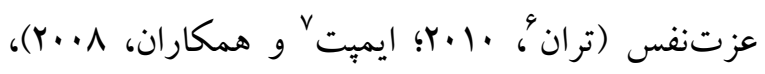
افزايش بهزيستى و كاهش بريشانى (وود و ديخران،

\footnotetext{
${ }^{8}$ - Kifer

9- Lakey

${ }^{10}$ - Goldner

11- Lenton

12- Meaning in life

13. Wong

14 - Krause

${ }^{15}$ - Baumann., Eiroa-Orosa
}

1- Authenticity
2- Schlegel
3- Wood
4- Goldman, Kernis
5- Alex
6- Theran
7- Impett




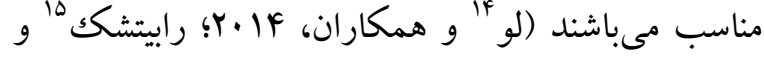

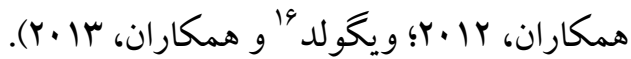
نتايج مطالعات انجامشده در رابطه با اقدام براى رشد شخصى نشان مىدهند كه اين سازه روابط مثبتى با

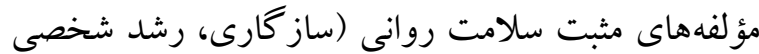
و خودمختارى، معنويت، مهارتهاى بين فردى،

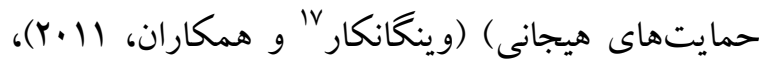

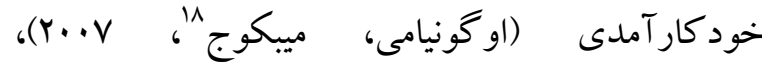
خود كار آمدى هيجانى (برى و جين، 19.Y)، شفقت به

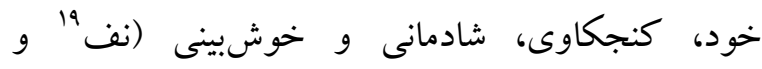

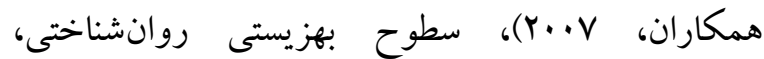
عزتنفس و ابعاد مثبت سلامت روان و رابطه منفى با

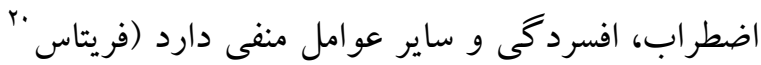

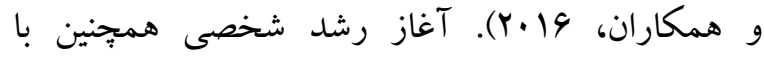
جستجوى كمككهاى حرفهاى روانشناسى (الويناكى"،

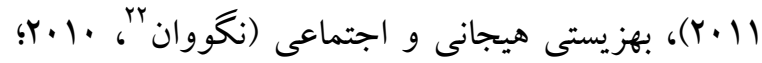

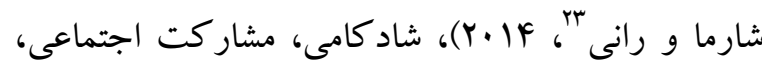

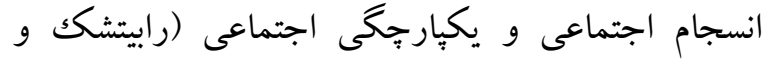

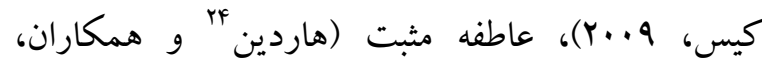
و و ب..VV همكاران، ها •r) در ارتباط است. از ديخر متغيرهاى مطرحشده در يزوهش حاضر، مفهوم جهت گيرى زندگى "rاست كه همسو با سير رو به رشد و

${ }^{14}$ - Loo, Tsai, Raylu

${ }^{15}$ - Ashton

${ }^{16}$ - Weigold

17. Vaingankar

${ }^{18}$ - Ogunyemi, Mabekoje

${ }^{19}$ - Neff

${ }^{20}$ - Freitas

${ }^{21}$ - Oluyinka

${ }^{22}$ - Negovan

${ }^{23}$ - Sharma, Rani

${ }^{24}$ - Hardin, Nixon

${ }^{25}$ - Malik

${ }^{26}$ - Life orientation
عاطفه مثبت، رضايت از زندگى بالا، خوشينى (استگر'

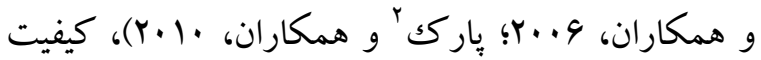
زندگى، سلامت و بهزيستى روانشناختى (باومن و ايروا-

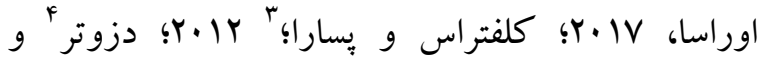

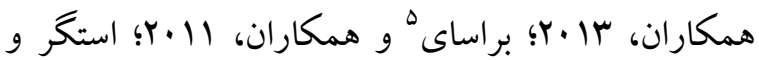

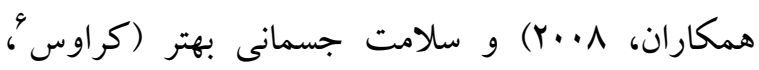

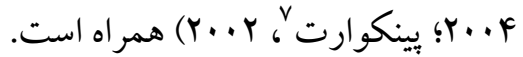

ويز كىهاى شخصيتى از قبيل اصالت همجينين ممكن است كه با شاخصهاى آغاز رشد شخصى در ارتباط

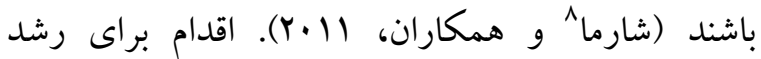

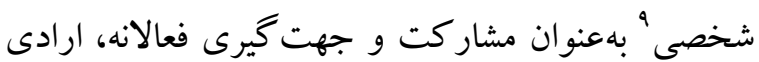
و آكاهانه فرد در فر آيند تغيير و تحول و بهعنوان تعهدى برنامهريزىشده، آكاهانه و فراشناختى جهت ارتقاى رشد شخصى در ابعاد مختلف زندكى تعريفشده است

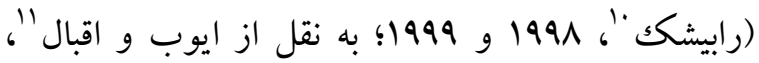

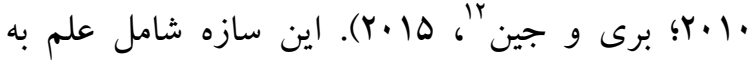

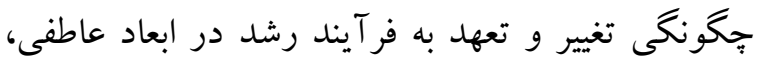

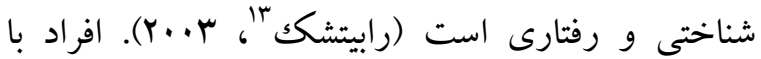
سطح بالاى رشد شخصى، بهتر با موقعيتهاى مختلف ساز گار مىشوند، بر شرايط براسترس غلبه مى كنند، سطوح بالايى از رضايت از زندگى را گزارش مى كنند و لئر در مواجه با موقعيتهاى بيش رو به دنبال راهحلهاى

\footnotetext{
1. Steger

${ }^{2}$ - Park

${ }^{3}$ - Kleftaras, Psarra

${ }^{4}$ - Dezutter

5 - Brassai

${ }^{6}$ - Krause

7- Pinquart,

${ }^{8}$ - Sharma

9 - Personal Growth Initiative

${ }^{10}$ - Robitschek

${ }^{11}$ - Ayub, Iqbal

${ }^{12}$ - Beri, Jain

${ }^{13}$ - Robitschek
} 


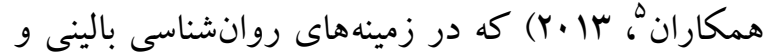

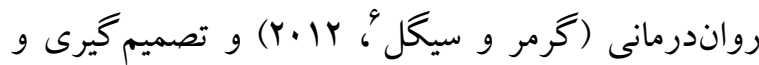
سياست گذارىهاى مربوط به سلامت (يانيو و جوسن

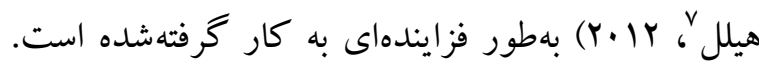

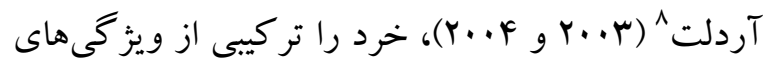
شخصيتى كه شامل سه مؤلفه شـناختى (توانـايى دركى موقعيـت بهطور كامل، آكاهى از جنبههاى مثبت و منفى ماهيت انسان، آكاهى از ابهامات لاينفك زند كى)، تأملى (توانايى و تمايل به بررسى يديدهها از جنبههاى مختلف و

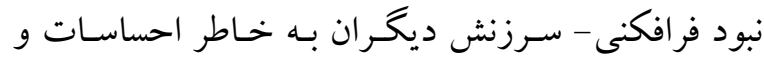
موقعيـت شخصى خـود) و ع عـاطفى (همدلى و و عشقورزى و شفقت نسبت به ديخران، رفتارها و هيجان مثبت و نبود بىتفاوتى و هيجانهاى منفى نسبت بـه ديخـران و حفـظ روحيه مثبت در مواجهه با سختىها) تعريف كرده است. گروسمن و همكاران" (19) خردمندى را توانايى استفاده از استدلال عمل گر ايانه براى حل جالشهاى مهم زندگى تعريف كردهاند. نتايج يثزوهشها نشان دادهاند كه خردمندى همبستكى مثبت و

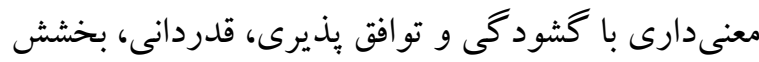

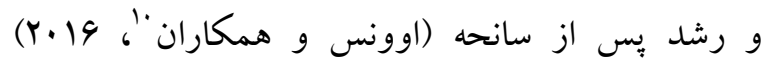
تسلط، بهزيستى ذهنى، زندگى هدفمند، سلامت ذهنى و روابط منفى با علائم افسردگى، اجتناب از مركى و و

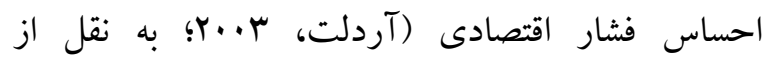

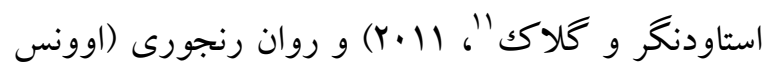

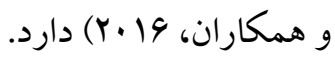

5- Gluck

${ }^{6}$ - Germer, Siegel

7- Yaniv

${ }^{8}$ - Ardelt

9. Grossmann, Sahdra, Ciarrochi

${ }^{10}$ - Owens

${ }^{11}$ - Staudinger, Gluck
علاقه روزافزون به مطالعه و تحقيق در رويكرد روانشناسى مثبت، بهعنوان يكى از شاخص هاى اصلى اين رويكرد طى يك دهه اخير جايگاه ويثهاى را در حوزه روانشناسى تحول، روانشناسى خـانواده و بهداشت روان به خود اختصاص داده است (يور سردار و همكاران، rوبr). تلقى خوش بينانه' و تلقى بدبينانه' بهورر مثبت و منفى دو طيف جهت گيرى زندگى هستند كه جز كيفيتهاى اساسى شخصيت به شمار مىروند و بر

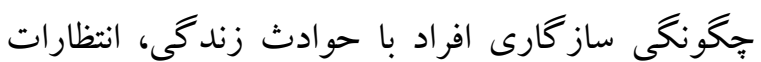
ذهنى افراد در هنكام مواجهه با مشكلات و رفتار آنها هنگام غلبه بر مشكلات تأثير مى گذارد (موسوى نسب و وراجها

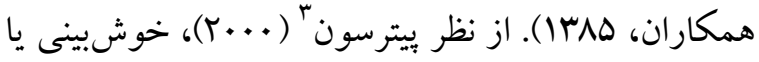
يا تفكر مثبت به جهت گيرى اشاره دارد كـه در آن معمولاً يِامدهاى مثبت مورد انتظارند و ايسن بيامـدها بهنوان عواملى ثابت، كلى و درونى در نظر كرفته

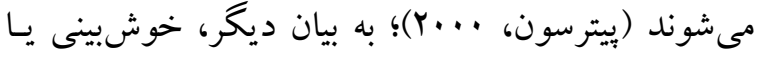
تفكر مثبت تمايل به اتخاذ اميدوارانهترين ديدكاه است؛ و و به يـك بــش آمـادكى عـاطفى و شناختى در خصوص له اين كه جيزهاى خوب مهمتر از جيزهاى بد است، اشاره دارد كه اين خود مستلزم آن است كه يـك شخص جَگ مى كند (يور سردار و همكاران، بrMa). خوشبينى و بلدبينى با سلامت روانشناختى و جسمانى بهتر و بدتر در

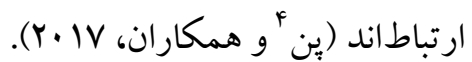
متغير ديخرى كه اخيراً در حوزه روانشناسى مثبت

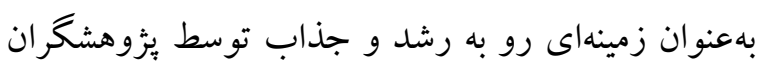
مطرحشده است، مفهوم خردمندى است (كلاكك و

\footnotetext{
1- Optimism

${ }^{2}$ - Pessimism

3 - Peterson

4- Pan
} 
تحولات در زندگى آنان و جامعه است و بهطور فزايندهاى زندگى تحصيلى و غير تحصيلى آنان و حتى ونى

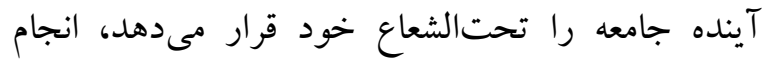

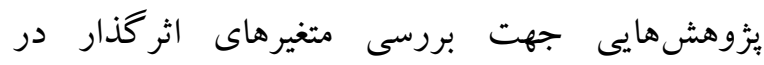
شخصيت و سلامت روان آنان ضرورى مىنمايد. با توجه به اين موارد يزوهش حاضر باهدف بررسى روابط

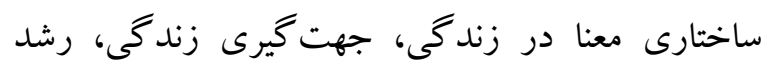
شخصى و خرد با اصالت شخصيت در دانشجويان انجام شد. مدل فرضى برزوهش از قرار زير بود (شكل ()).
عليرغم اينكه سازههايى از قبيل اصالت؛ خرد، رشد

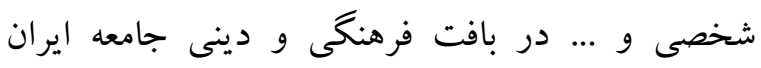
ارزشهايى والا و قدمتى كهندارند، اما متأسفانه تاكنون

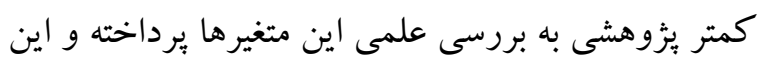

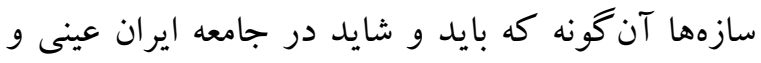
علمى نشدهاند. همجنين با توجه به نقش انكارنايذير دانشجويان در ويشبرد اهداف علمى و اجتماعى حال و لنال

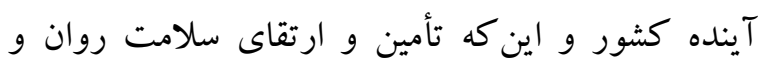
توانمندىهاى شخصيتى دانشجويان، مبناى بسيارى از ازئ

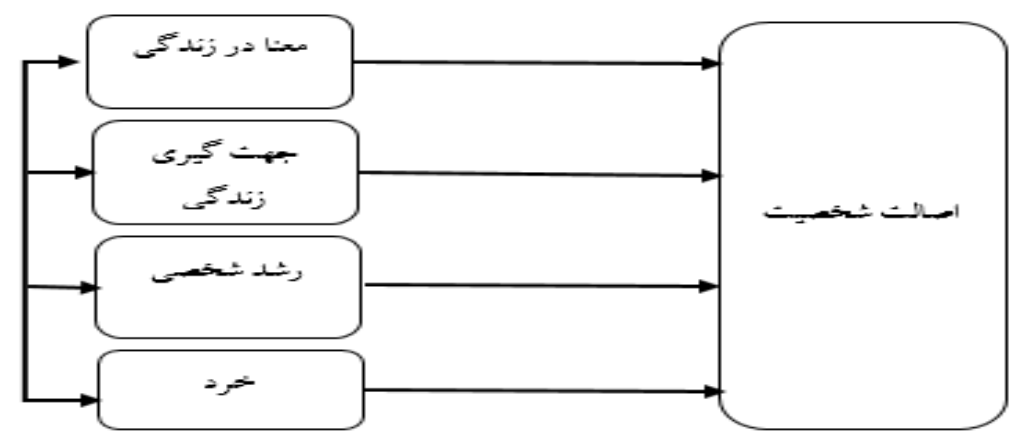

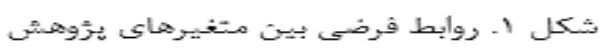

يوسشنامه معنا در زندكى (MLQ): يرسشنامه معنا در

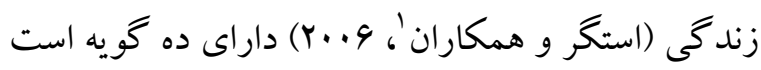

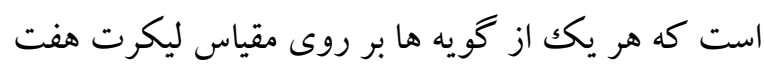

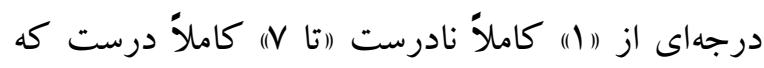

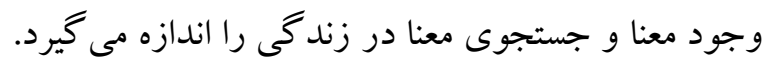

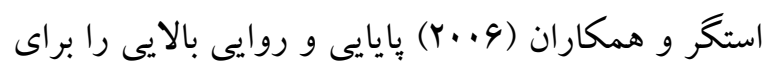

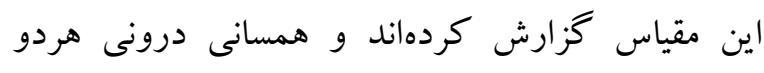

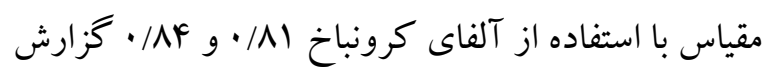

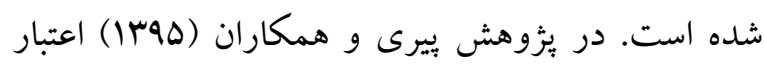

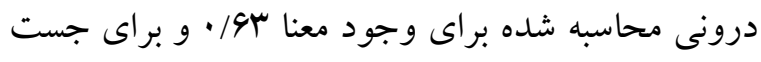

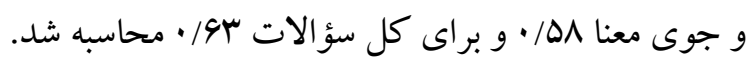

روش روش بزوهش توصيفى از نوع همبستخى است كه در

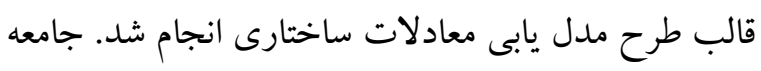

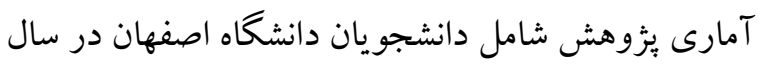
تحصيلى 99- هوج| بود كه با استفاده از شيوه نمونه گيرى در دسترس تعداد 199 نفر (ها نفر بسر و ایم نفر دختر) يس از كسب رضايت آكاهانه و ذكر هدف از انجام

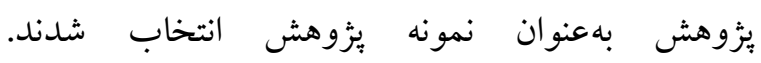
تجزيهو تحليل دادهها با استفاده از بيست و سومين وير ايش لند نرمافزارهاى SPSS و Amos انجام شدائ 
بسيار درست است تا ( اصلاً درست نيست) دامنه دارند.

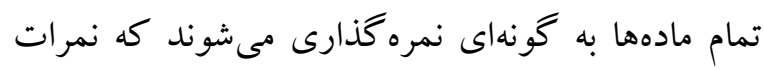

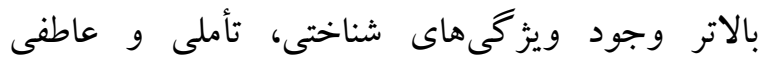

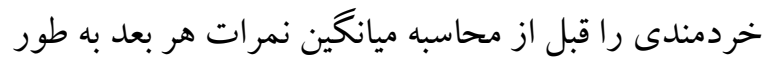

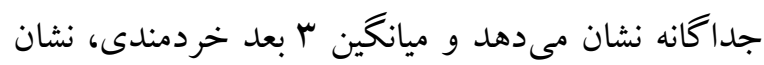
دهنده نمره كلى خردمندى فرد است. در يُووهش آردلت در ارزيابى روايى و اعتبار اين مقياس، آلفاى كرونباخ

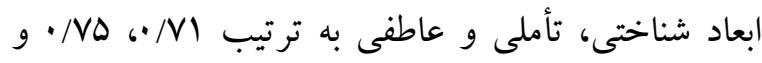

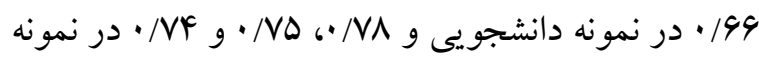

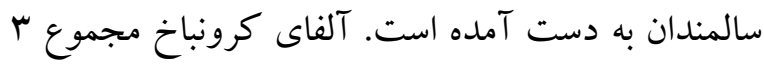

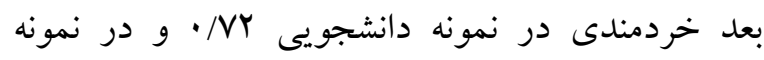

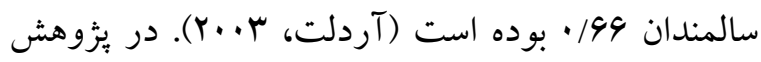

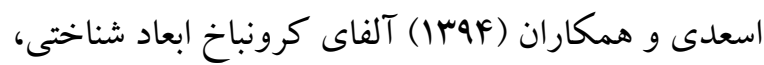
تأملى و عاطفى در بازه ال/ • تا هی/· قرار داشت. بررسى اعتبار مقياس سه بعدى خردمندى همسانى درونى رضايت داطي بخش تا خوبى را براى مقياس سه بعدى خردمندى به طور

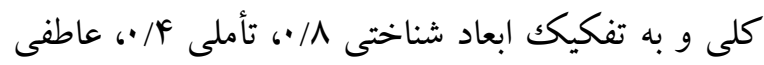

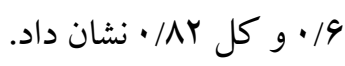

مقياس شخصيت اصيل - فرم r آ سؤالى: مقياس شخصيت

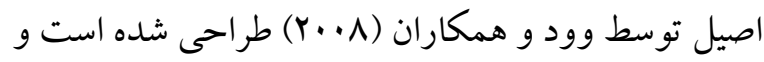

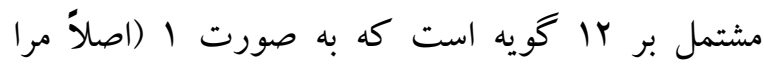

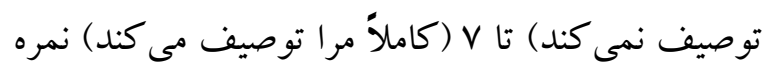

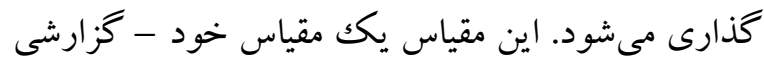

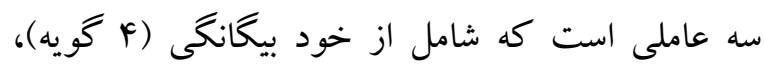

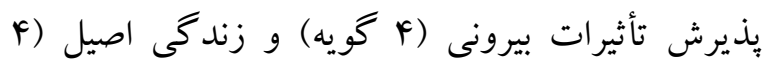

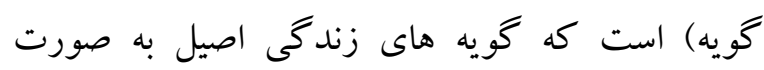
معكوس نمره گذارى مىشود. وود و همكاران (1) (r) ضريب هايايى اين مقياس را از طريق روش باز آزمايى بين

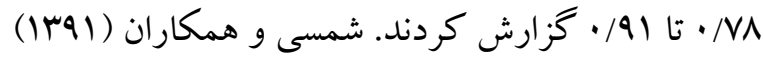

مقياس اقدام براى رشد شخصى: اين مقياس را رابيكك

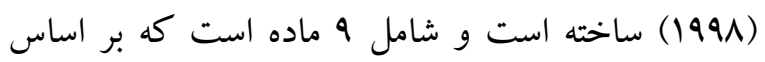

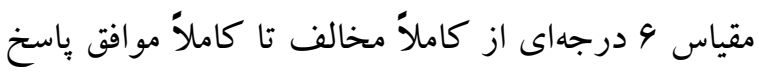

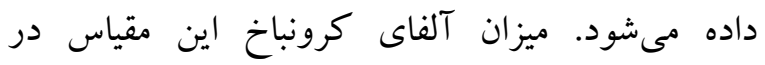

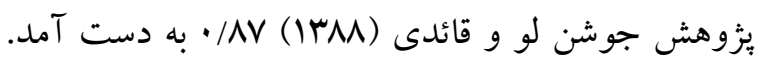
تحقيقات اعتبار يابى مقياس رشد شخصى نشان دهنده

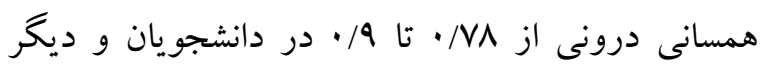

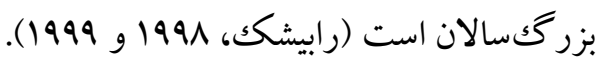

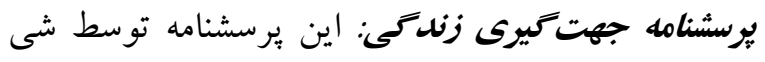

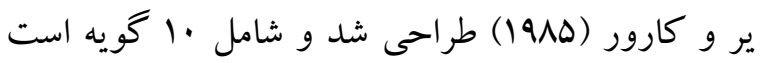

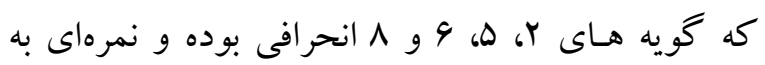

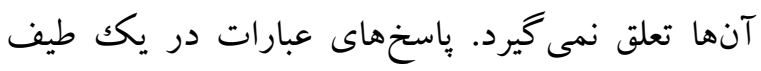

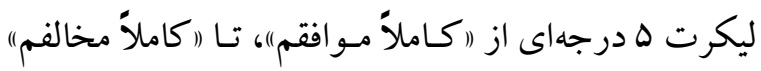

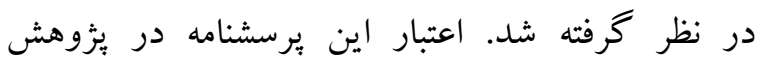

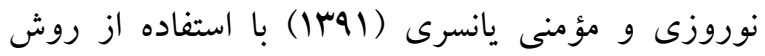

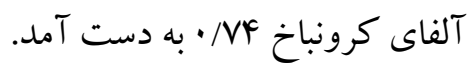
مقياس سه بعلدى خردمندى' (YD-WS): اين مقياس كه

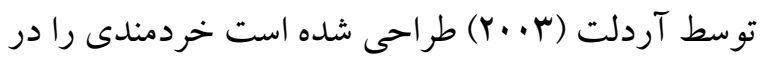

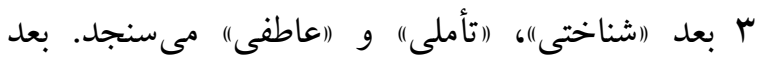

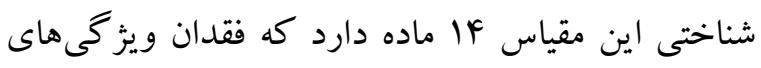
شناختى خردمندى را مىسنجد.rا ماده بعد تأملى، توانايى و تمايل نظر كردن به بديدهها و رويدادها را از

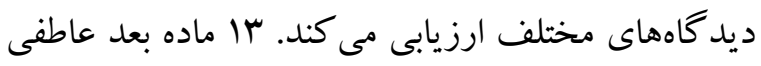
نيز وجود رفتار و هيجانات مثبت، (همدلانه)) و (إيرورش دهنده و عدم وجود هيجانات و رفتارهاى منفى يا

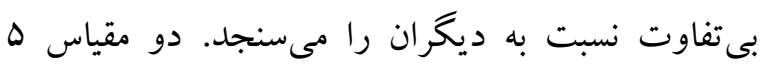

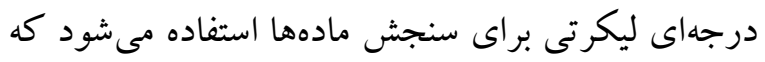

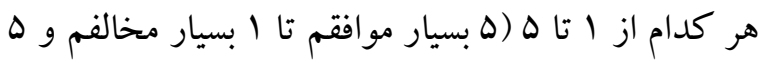

1. 3 Dimensional Wisdom Scale (3D-WS) 
دامنه سنى شركت كنند گان در يثزوشش از 19 تا بم و در يزوهشى ضرايب آلفاى كرونباخ را براى خرده مقياس

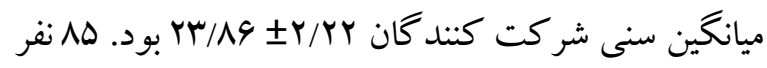
از خودبيكانكى، زندگى اصيل، بذيرش نفوذ بيرونى و از شركت كنند كان يسر و ای نفر دختر بودند. بی نفر از

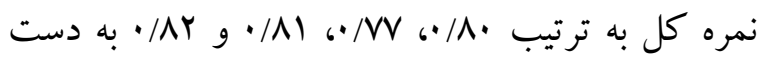
شركت كنند كان از مقطع تحصيلى كارشناسى، لف VY نفر

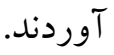
كارشناسى ارشد و 11 نفر از مقطع تحصيلى دكترى بودند. يافتهاى توصيفى متغيرهاى يُزوهش در جدول 1 يافتهها

$$
\text { آمده است. }
$$

جدول ا يافتههاى توصيفى مربوط به متغيرهاى يزوهش إن

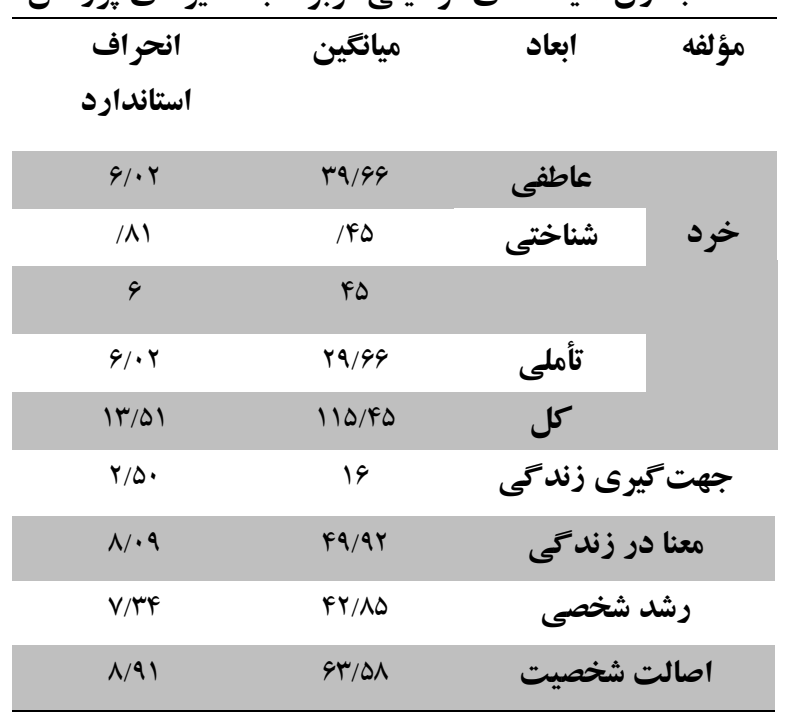

r و r گز ارششده است. در مرحله بعد براى ارزيابى روابط على بين متغيرهاى موردمطالعه از نرمافزار بmos استفاده شد.
بهمنظور تجزيه و تحليل آمارى دادههاى يثوهش، ابتدا بر اى بررسى نرمال بودن متغيرهاى مورد مطالعه و همجينين

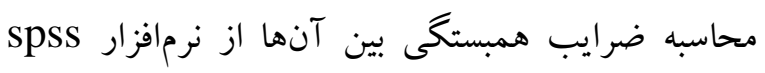
ويراست سץ استفاده گرديد كه نتايج آن در جدول شماره

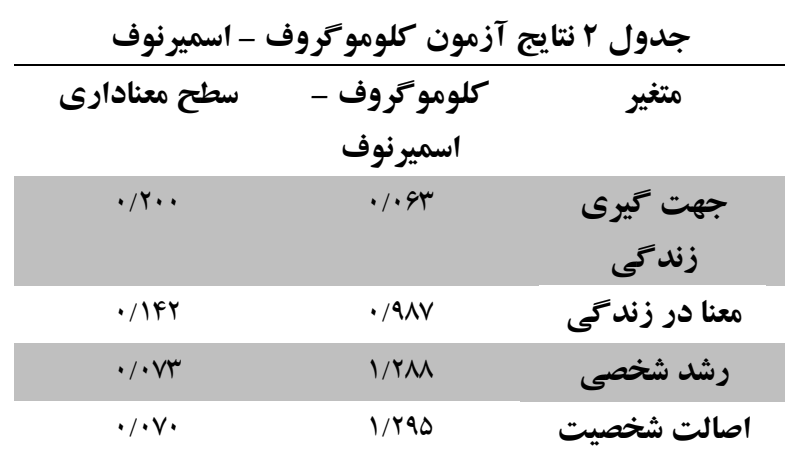


بررسى روابط على بين متغيرها، همبستخى آنها از طريق

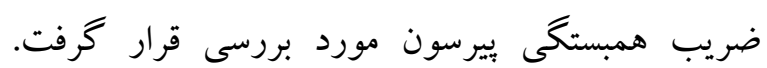
جدول ب نتايج ضريب همبستخى به دست آمده بين اصالت و متغيرهاى بثزوهش را نشان مىدهد.
همانطور كه در جدول r ملاحظه مىشود، با توجه به سطح معنادارى به دست آمده براى هر ينج متغير اصلى

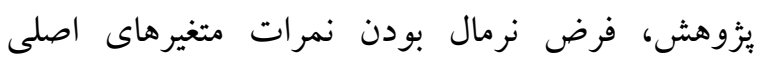

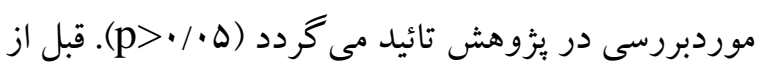

\section{جدول ץ نتايج همبستكى پيرسون بين متغيرهاى يخوهش}

\begin{tabular}{|c|c|c|c|c|c|}
\hline$\Delta$ & r & $r$ & $r$ & 1 & متغير ها \\
\hline & & & & 1 & اصالت \\
\hline & & & 1 & $\cdot / \Delta \Delta Q^{* * * *}$ & جهت كيرى زندكى \\
\hline & & 1 & Drו/. & $\cdot / Y 9 \Lambda^{* * * *}$ & معنا \\
\hline & 1 & $\cdot / r V V^{* * * * *}$ & $\cdot / r \cdot \Lambda^{* * * *}$ & $\cdot / F F D^{* * * *}$ & رشد شخصى \\
\hline 1 & $\cdot / r \cdot r^{* *}$ & $\cdot / r M 4^{* * * * *}$ & $\cdot / Y 99^{* * * * *}$ & $\cdot / f \cdot f^{* * * *}$ & خرد \\
\hline
\end{tabular}

$\mathrm{P}<\cdot / \cdot 1 * *$

بنابر نتايج حاصل از جدول آ، ضريب همبستگى منظور بررسى فرضيهها و آزمون مدل مفهومى يثوهش، دادهاى جمع آورى شده از طريق معادلات ساختارى تحليل شد. نتايج به دست آمده در شكل r r، قابلمشاهده

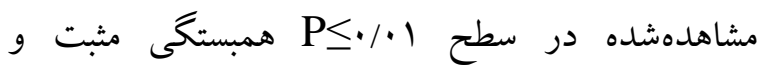

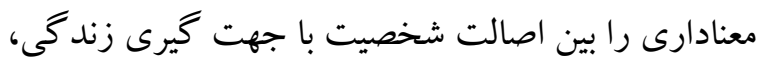
معنا در زندگى، رشد شخصى و خرد نشان مىدهد. به است.

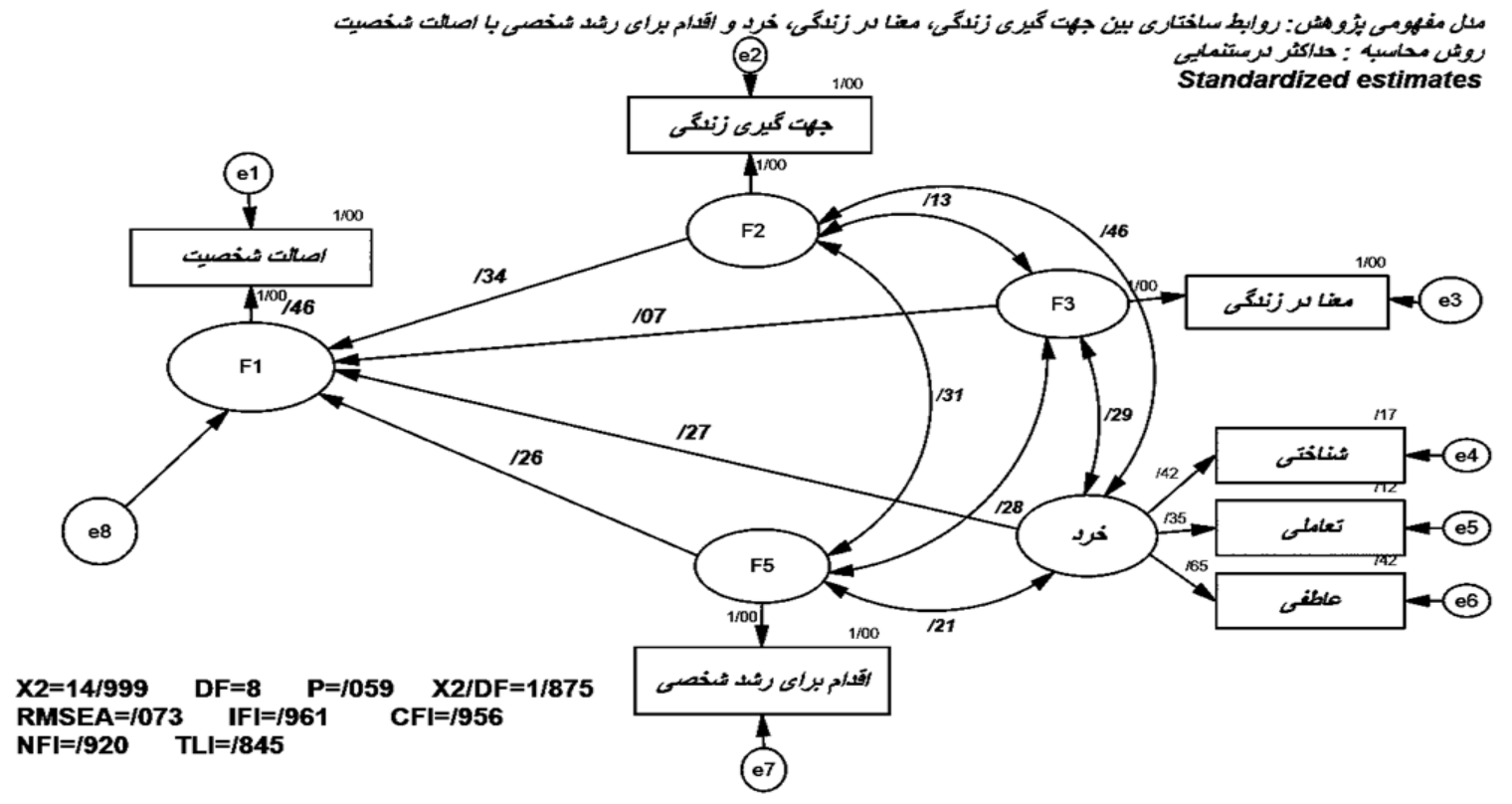


معنادارى مجذور خى بزرگكتر از هـ/•؛ خطاى تقريبى

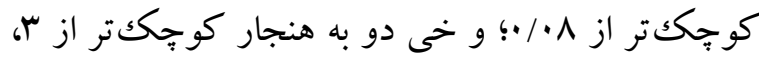
دلالت بر برازش مطلوب مدل دارد. بر اساس اين نتايج مى توان نتيجه گرفت كه مدل از برازش مطلوب برخوردار است و ساختار كلى روابط مورد آزمون از طريق دادههاى بهدست آمده تائيد مىشود. شاخصهاى تائيد الخوى

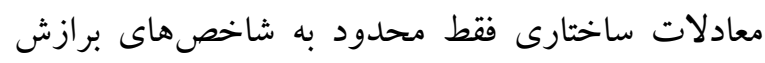
كلى الكو نيست، بلكه بايد بارامترهاى استاندارد ضرايب

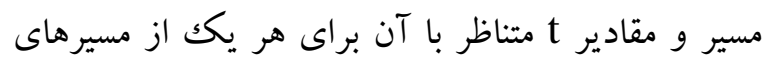

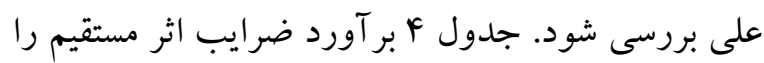
نشان مى دهد.
بهمنظور بررسى برازندگى الخوى معادلات ساختارى مرتبه اول از شاخصهاى مجذور خى، سطح معنادارى مجذور خى، شاخص جذر برآورد خطاى تقريبى، خى دو به هنجار، شاخص برازش هنجار شده، شاخص برازندگى فزايند، شاخص برازش تطبيقى و شاخص تاكر

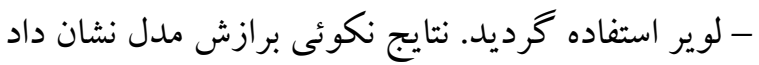
كه شاخص جذر برآورد خطاى تقريبى، خى دو به هنجار، سطح معنادارى مجذور خى، شاخص برازش هنجار شده، شاخص برازندگى فزايند، شاخص برازش

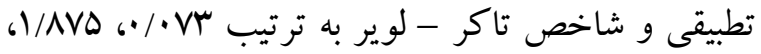
. شاخص هاى برازندگى فزايند، برازش هنجار شده، برازش تطبيقى و تاكر - لوير داراى دامنه صفرتا يكك هستند،

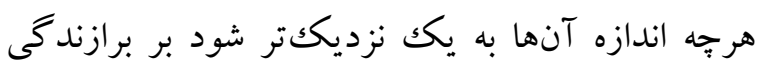
مطلوبتر الكو دلالت دارند. همجنين زمانى كه سطح

\begin{tabular}{|c|c|c|c|}
\hline سطح معنادارى & 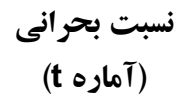 & ضريب مسير & مسير \\
\hline$\cdot / \cdots$ & $F / \mid \Delta \wedge$ & - MFT & جهت كيرى زندكى \\
\hline$\cdot / \mu \cdot v$ & I/.rY & $\cdot / \cdot v$ & معنا در زندكى \\
\hline ( ) & r/Ird & $\cdot / T V I$ & اقدام به رشد شخصى \\
\hline$\cdot / \cdots$ & $F / .19$ & $\cdot$ /rgF & خرد \\
\hline
\end{tabular}

حدود F4 درصد از واريانس اصالت شخصيت را تبيين مىنمايند. با توجه به سطوح معنادارى به دست آمده مىتوان گفت كه تأثير جهت گيرى زندگى، خرد و اقدام براى رشد شخصى بر اصالت شخصيت معنادار است
همانطور كه در جدول F مشاهده مىشود، نتايج ضريب اثر مستقيم نشان مىدهد كه جهت گيرى زندگىى، معنا در

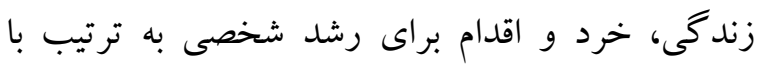

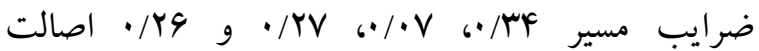
شخصيت را تحت تأثير قرار مىدهند و در تعامل با هم 
نيز فراهم مى كنند و به رشد و شكوفايى افراد كمك كنند.

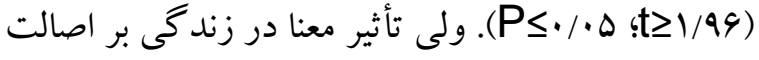

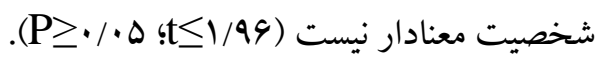

از سويى اعتقاد بر اين است كه اصالت شخصيت نيز مى تواند متأثر از عوامل فردى و شخصيتى باشد، در همين راستا نتايج يزوهش نيز نشان داد كه اصالت شخصيت كه

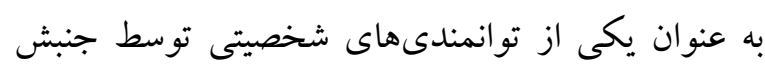

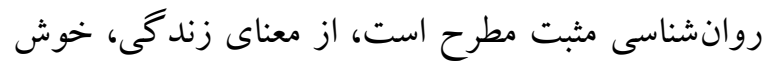

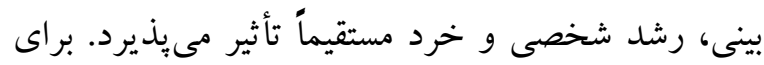
مثال آردلت نيز خرد را تركيبى از شايستخىها و و ويز گیىاى شخصيتى مىداند كه صفات شخصيتى

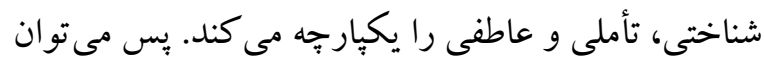

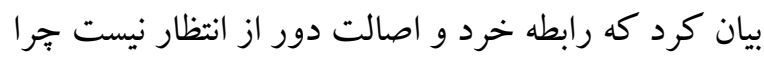
كه بين اين دو مؤلفه در معنا و مفهوم، هميوشانىهايى وجود دارد و مىتوان گفت كه رگههايى از اصيل بودن در افراد خردمند بايد وجود داشته باشد. همجِنين محققان معتقدند كه ويز گى هاى مثبت شخصيت از قبيل اصالت مىتواند باعث تغييرات مشخصى در جنبههاى عاطفى، شناختى و رفتارى افراد شود؛ حيطههايى كه با سه بعد خرد مطرحشده توسط آردلت تقريباً هماهنگك و همسو هستند. يس مى توان نتايج يُزوهش حاضر را در رابطه با روابط اصالت شخصيت با خرد دانشجويان تأييدى بر اين ين برون مدعا دانست. بخشى ديكر از نتايج يثوهش نشان داد كه بين اقدام براى رشد شخصى و اصالت رابطه وجود دارد. در تبيين رابطه اقدام براى رشد شخصى و اصالت مىتوان كفت كه اين دو سازه از اساس و مبنا داراى يكك بايه نظرى مشترك و همخوان مىباشند كه افزايش در يكى از اين متغيرها، سبب تسريع روند متغير ديخر خواهد شد. از سويى هرجه. رشد شخصى بيشتر باشد زمينه را براى اصالت شخصيت

\section{يثزوهش حاضر با هدف بررسى روابط ساختارى جهت}

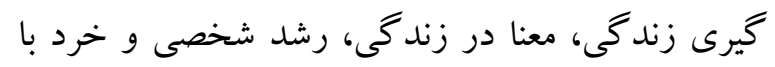
اصالت شخصيت در دانشجويان انجام شد. نتايج نشان داد بين مؤلفههاى جهت گيرى زندگى، معنا در زندگى، رشد اصند شخصى و خرد با اصالت شخصيت در دانشجويان رابطه مثبت و معنى دارى وجود دارد و با هم حدود \&4 درصد از تغييرات اصالت شخصيت را در دانشجويان بيش بينى مى كنند. يافتها از برازندگى مناسب ساختار فرضى إسى متغيرهاى يزوهش حمايت كرد و نتايج حاكى از وجود

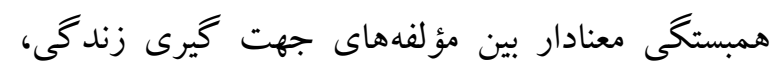
اقدام براى رشد شخصى، اصالت شخصيت و معنا در زندكى بود. يافتهاى يُزوهش حاضر علاوه بر همسو بودن با مبانى نظرى و يافتهاى بيشين در اين زمينه،

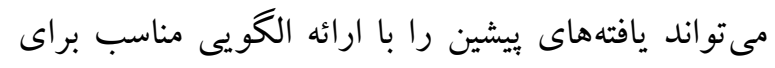
روابط بين متغيرهاى يزوهش بسط دهد. در تبين نتايج يثزوهش حاضر مىتوان كفت كه هر ينج متغير مطرحشده در يثزوهش حاضر از يكك مبناى نظرى و

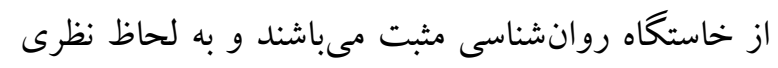
ارتباط اين مؤلفهها باهم دور از انتظار نيست. ازآنجاكه روانشناسى مثبت نه تنها براى بهبود بخشيدن و بنا نهادن

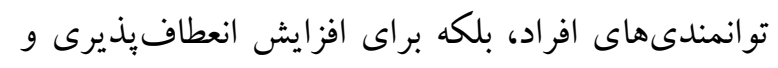

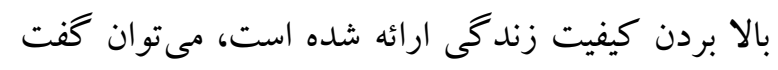
كه توانمندىهايى از قبيل اصالت به سلامتى فرد و نيازهاى روانشناختى اوليه او كمكك مى كند و زمينه را براى كسب خرد و رشد شخصى و به تبع آن افزايش و غناى معنا در زندگى و جهت گيرى مثبت و خوش بينى 
دشوارىها، به دنبال كردن هدفهاى با ارزش خود ادامه مىدهند و با به كار گيرى راهبردهاى كنار آمدن مؤثر، خودشان و حالتهاى شخصى شان را تنظيم مى كنند تا اين كه بتوانند به هدف هاى خود برسند. اين حالتها و

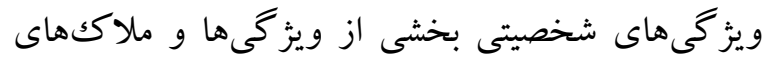
شخصيت اصيل نيز مىباشند در نتيجه مىتوان كفت كه جهت گيرى زندكى خوش بينانه مىتواند بخشى از تغييرات مربوط به اصالت شخصيت را بيش بينى كند و كيفيتهاى جهت گيرى زندكى خوش بينانه قادر به بيش بينى شخصيت اصيل افر اد خو اهند بود. امروزه اعتقاد روزافزونى در رابطه با نقش فرهنگك در اردي ادبيات روان شناسى بين متخصصان اين حوزه شكل كرفته است و اعتقاد بر اين است كه نمىتوان نقش فرهنگ را در ادبيات روانشناسى و نتايج ئزوهشهاى اين حوزه ناديده گرفت. در همين راستا و در تبيين نتايج يزوهش حاضر با توجه به بافت و فرهنگك جامعه ايران مىتوان كفت كه مفاهيمى از قبيل اصيل بودن، خردورزى و خردمندى، خوش بينى و رشد شخصى داراى سابقه و ريشههاى كهنى هستند كه تا حدود زيادى با فرهنگ و آداب و رسوم اين سرزمين عجين شده است.

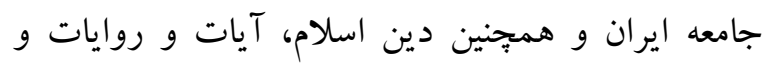

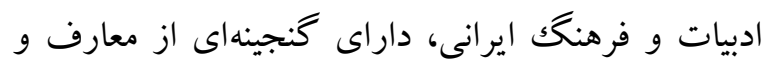
تلويحاتى هستند كه اهميت و ضرورت اصيل بودن، ارتقاى رشد شخصى و شناخت خويشتن و اصالت وجودى و خردورزى را مىرسانند. بِ مى توان كفت كه اين مفاهيم براى جامعه يُوهش حاضر مفاهيمى غريب نيستند و جامعه دانشجويى ايران بهخوبى با اين مفاهيم

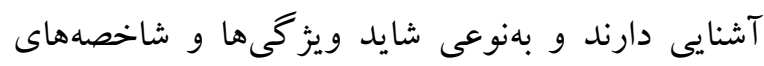
هر كدام از اين مفاهيم تا حدى در وجود هريك از افراد
فر اهم مى كند. يُزوهشهاى حوزه روانشناسى مثبت نشان دادهاند كه افرادى كه هيجانات مثبت و توانمندىهاى شخصيتى از قبيل اصالت را تجربه كرده باشند در زمينه تحقق خويشتن سالم شرايط بهترى را نسبت به ديكر افراد دارند (نامدارى، ملكك يور و مولوى، مى توان در تبيين رابطه اقدام براى رشد شخصى و اصالت شخصيت در نظر كرفت و نيز مىتوان كفت كه انتظار مىرود كه تلاش آكاهانه و ارادى براى رشد دادن خود، هم منجر به شكوفا شدن استعدادهاى بشرى در وجود فرد و هم منجر به تجربه هيجانات و حالات مثبتى از قبيل اصالت شخصيت شود. بخش ديخرى از يافتهاى يثزوهش نشان داد كه بين جهت گيرى زندگى و اصالت شخصيت رابطه وجود دارد و با افزايش جهت كيرى خوش بينانه ميزان اصالت شخصيت

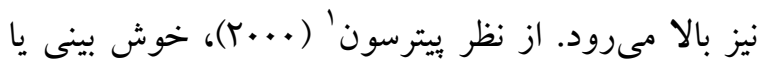
تفكر مثبت به جهت گيرى اشاره دارد كـه در آن معمولاً ييامدهاى مثبت مورد انتظارند و ايسن ييامـدها بـه عنوان عواملى ثابت، كلى و درونى در نظر كرفته مىشوند

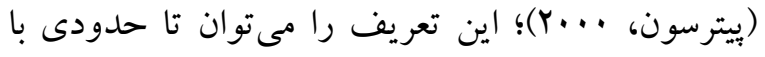
تعاريف مربوط به اصالت شخصيت همبسته و در يكك راستا دانست جرا كه از ويز كىهاى شخصيت اصيل نيز اين است كه اين افراد داراى ساختار هويتى باثباتى هستند و بر طبق اين هويت عمل مى كنند. همبِنين در رابطه با ييامدهاى درونى خوش بينى كه به آن اشاره شد مىتوان كفت كه با آن بخش از ملاككهاى شخصيت اصيل كه بر عدم بذيرش از تأثيرات بيرونى و از خود بيشانكى بايين تمركز دارند، همخوانى دارد. مطابق با ادبيات نظرى و يثزوشى موجود، افراد خوش بين در رويارويى با

${ }^{1}$ - Peterson 
يثوهش حاضر نيز مانند ساير يزوهشهاى حوزه علوم رفتارى محدوديتهايى دارد؛ ازجمله اين محدوديتها اين است كه دادههاى يُزوهش حاضر با برسشنامههاى

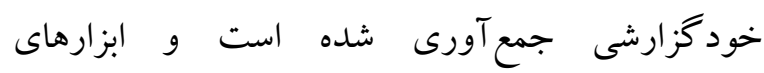
خود گزارشى هميشه تحت تأثير دو متغير مداخله خر ارائه خودمثبت و بكدقتى افراد در قضاوتهايشان از خود هستند؛ همجنين اين بزوهش صرفاً در محيط دانشگاه اصفهان و روى دانشجويان انجامشده است و در تعميميافتها ها به ساير جمعيتها، دامنه هاى سنى و محيطها

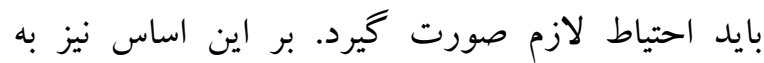

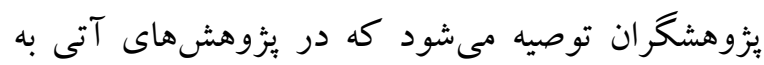
بررسى ساير متغيرها و مؤلفههاى مرتبط با اصالت شخصيت و همبِنين در دامنهاى سنى مختلف و اجراى مقايسهاى در دو جنس يسر و دختر بيردازند.

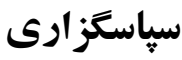
بدينوسيله از كليه دانشجويان عزيزى كه در انجام اين يثزوهش ما را همكارى نمودند، قدردانى مى شود.

\section{References}

Ahmadi Gh, Sohrabi F, Barati Sadeh F, Ghaderi M. (2015). Studying the predictive role of life meaning in students depression, Quarterly Journal of Counseling and Therapy, 4 (14): 89- 103. (in Persian)

Ardelt M. (2004). Wisdom as expert knowledge system: a critical review of a contemporary operationalization of an ancient concept. Hum Dev; 47:257-85.

Asadi S, Amiri SH, Molavi H. (2015). Wisdom transformation from adolescence to old age;19(1):37-52. (in Persian)

Ayub N, Iqbal S. (2012). The relationship of Personal Growth Initia-tive, Psychological Well-Being, and Psychological Distress among Ado-
نهادينه شده است و مىتوان كفت كه همه اين مفاهيم علاوه بر ادبيات روانشناسى، از راه ادبيات، فرهنگك و آدابورسوم و احكام اسلام در وجود افراد رخنه كردهاند و افرادى كه داراى ميزان مشخصى از هريكك از اين مؤلفها باشند، بهتبع در ساير مؤلفهها نيز به همان ميزان داراى قابليتهايى خواهندبود (قادرى، كجباف،

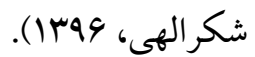
بهور كلى مى توان كفت كه همان گونه كه كسب و رشد توانمندىها و مؤلفهاى مثبت سلامت روانشناختى مىتواند باعث افزايش سطح رشد فردى و شخصيتى و اصالت شخصيت شود، به فعل درآوردن اصالت در زندكى نيز ممكن است وسيلهاى براى ارتقا و رشد توانمندىها و افزايش سطح رشد فردى و بهزيستى روانشناختى باشد.

\section{نتيجه كيرى}

به طور خلاصه نتايج يزوهش نشان داد كه مؤلفهاى

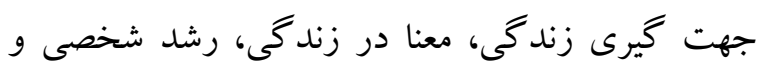
خرد از بيش بينى كنندههاى اصالت شخصيت در دانشجويان مىباشند. با استناد به يافته هاى بثزوهش حاضر مى توان به دانشخاهيان، روانشناسان، روانيزشكان و ساير متخصصان مرتبط بيشنهاد كرد كه به نقش توانمندىهاى شخصيتى از قبيل اصالت شخصيت، خوش بينى، معنا در زندگى و اقدام براى رشد شخصى در راستاى رئ توانمندسازى مراجعه كنند كان توجه ويزهاى داشته باشند و با تدوين برنامهايى جهت آموزش اين مؤلفهها و

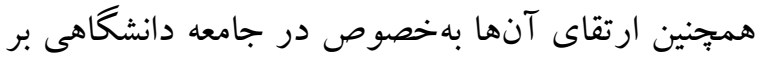
اساس مؤلفههاى مذكور سعى در ارتقاى شخصيت اصيل و اصالت دانشجويان داشته باشند. 
lescents. Joumal of Teaching and Education; 1(6):101-7.

Bahadori Khosroshahi J, Mahmood Alilu M. (2012). Studying Identity Styles With the Meaning of Life in Students.. Joumal of Psychological Studies, Faculty of Educational Sciences and Psychology, Alzahra University;8(2). (in Persian)

Beri N, Jain M. (2016). Personal Growth Initiative among Undergraduate Students: Influence of Emotional Self Efficacy and General Well Being. Rupkatha Joumal on Interdisciplinary Studies in Humanities; 8(2):43-56.

Beyrami M, Hashemi Nosratabad T, Daneshfar SH, Bahadori Khosroshahi J. (2013). The role of positive and negative emotions, optimism and pessimism and information processing styles in students' psychological adjustment. Quarterly Joumal of Cognitive Psychology;1(1):1-8. (in Persian)

Brassai L, Piko BF, \& Steger MF. (2011). Meaning in life: Is it a protective factor for adolescents' psychological health? International Journal of Behavioral Medicine, 18, 44-51.

Brown SC, Greene JA. (2008). The Wisdom Development Scale: Translating the conceptual to the concrete. Journal of College StudentDevelopment; 47:1-19.

Dezutter J, Casalin S, Wachholtz A, Luyckx K, Hekking J, \& Vandewiele W. (2013). Meaning in life: An important factor for the psychological well-being of chronically ill patients? Rehabilitation Psychology, 58(4), 334341. doi: 10.1037/a0034393

Doris Baumann, Francisco JE. (2017). Mental WellBeing in Later Life: The Role of Strengths Use, Meaning in Life, and Self-Perceptions of Ageing, Int J Appl Posit Psychol (2016) 1:2139.

Freitas C, Damasio BF, Tobo PR, Kamei HH, Koller SH. (2016). Systematic Review about Personal Growth Initiative. anales de psicologia;32(3):770-82.

Garcia-Alandete J. (2015). Does Meaning in Life Predict Psychological Well-Being? The
European Journal of Counselling Psychology, 3(2).

Germer CK, Siegel RD. (2012) Wisdom and compassion in Psychotherapy: Deepening mindfulness in clinical practice. New York: Guilford Press.

Ghaderi F, kajbaf M, shokrollahi M. (2018). The Structural Relationship of personality virtues, authentic personality and Personal Growth initiative with. wisdom in students;11(4):1-15. (in Persian)

Gluck J, Konig S, Naschenweng K, Redzanowski U, Domer L, Straber I, et al. (2013). How to measure wisdom: content, reliability, and validity of five measures. Personality Science and Individual Differences; 4:1-13.

Goldman BM, Kemis MH. (2002). The role of authenticity in healthy psychological functioning and subjective well-being. Annals of the American Psychotherapy Association; 5:18-20.

Goldner L, Berenshtein-Dagan T. (2016). Adolescents' true-self behavior and adjustment: The role of family security and satisfaction of basic psychological needs. Merril-Palmer Quarterly; 62:48-73.

Grossmann I, Sahdra BK, Ciamochi J. (2016). A Heart and A Mind: Selfdistancing Facilitates the Association Between Heart Rate Variability, and Wise Reasoning. Frontiers in Behavioral Neuroscience; 10(68):1-10.

Hardin EE, Weigold IK, Robitschek C, Nixon AE. (2007). Self-discrepancy and distress: The role of personal growth initiative. Journal of Counseling Psychology; 54(1):86-92.

ImpettEA, Sorsoli L, Schooler D, Henson JM, Tolman DL. (2008). Relationship authenticity and girls' selfesteem across adolescence. Developmental Psychology; 44:722-33.

Joaquin, Garcia-Alandete. (2015). Does Meaning in Life Predict Psychological Well-Being? An Analysis Using the Spanish Versions of the Purpose-In-Life Test and the Ryff's Scales, The European Journal of Counselling Psychology, 3(2), 89-98. 
Joshanloo M, Ghaedi GH. (2009). Psychometric characteristics of "Personal Growth Initiative" scale in university students. Journal of Behavioral Sciences;3(2):121-5. (in Persian)

Kashubeck-West S, Meyer J. (2008). The well-being of women who are late deafened. Joumal of Counseling Psychology; 55(4):463-72.

Kifer YH, Heller D, Perunovic WQE, Galinsky AD. (2013). The good life of the powerful: The experience of power and authenticity enhances subjective well-being. Psychological Science;24:280-8.

Kleftaras G, \& Psarra E. (2012). Meaning in life, psychological well-being and depressive symptomatology: A comparative study. Psychology, 3(4), 337-345. doi:10.4236/psych.2012.34048

Kleftaras G, Psarra E. (2012). Meaning in Life, Psychological Well-Being and Depressive Symptomatology: A Comparative Study, Psychology 2012. Vol.3, No.4, 337-345.

Krause N. (2004). Stressors arising in highly valued roles, meaning in life, and the physical health status of older adults. The Joumals of Gerontology: Social Sciences, 59B, 287-297. doi:10.1093/geronb/59.5. S287.

Lakey CE, Kemis MH, Heppner WL, Lance CE. (2008). Individual differences in authenticity and mindfulness as predictors of verbal defensiveness. Joumal of Research in Personality; 42:230-8.

Lenton AP, Bruder M, Slabu L, Sedikides C. (2013). How does "being real" feel? The experience of state authenticity. Joumal of Personality and Social Psychology; 81:276-89.

Lenton AP, Slabu L, Sedikides S, Power K. (2013). I feel good, therefore I am real: Testing the causal influence of mood on state authenticity. Cognition and Emotion; 27:1202-24.

Loo JMY, Tsai J-S, Raylu N, Oei TPS. (2014). Gratitude, Hope, Mindfulness and PersonalGrowth Initiative: Buffers or Risk Factors for Problem Gambling. Plos One; 9(2).

Malik NI, Yasin G, Shahzadi H. (2015). Personal Growth Initiative and Self Esteem as Predictors of Academic Achievement among
Students of Technical Training Institutes. Pakistan Joumal of Social Sciences (PJSS); 35(2):703-14.

Maltby John Wood, Alex M, Diana Pinto, Liz Day (2012). The position of authenticity within extant models of personality. Personality and Individual Differences 52. 269-273.

Mousavinasab M, Taghavi M, Mohammadi N. (2006). Optimism and stress assessment: A review of two theoretical models in predicting psychological adjustment. Joumal of Kerman University of Medical Sciences;13(2):111-20. (in Persian)

Namdari k, Molavi H, Malekpour M, Kalantari M. (2010). The Effect of Cognitive Education on Promoting Hope on Personality Abilities of Depressed Patients. Joumal of Clinical Psychology;1(3):21-34. (in Persian)

Neff KD, Rude SS, Kirkpatrick KL. (2007). An examination of selfcompassion in relation to positive psychological functioning and personality traits. Joumal of Research in Personality; 41:908-16.

Negovan V. (2010). Dimensions of students' psychosocial well-being and their measurement: Validation of a students' Psychosocial Well Being Inventory. Europe's Joumal of Psychology; 6(2):doi:10.5964/ejop.v6i2.186

Nejati V, Kamari S, Shahidi S. (2017). Positive Recognition: The Relationship between Positive and Negative Referral Traits and Positive. Quarterly joumal of research in psychological health:; 2(11):1-18. (in Persian)

Nownuzi A, MoemeniYaseri I. (2012). General selfefficacy, life expectancy and life orientation in elderly women receiving education. Contemporary Psychology. 7:3146-9. (in Persian)

Ogunyemi AO, Mabekoje SO. (2007). Self-efficacy, risk-taking behavior and mental health as predictors of personal growth initiative among university undergraduates. Electronic Joumal of Research in Educational Psychology; 5:349-62. 
Oluyinka O. (2011). Psychological predictors of attitude towards seeking professional psychological help in a Nigerian university student population. South African Joumal of Psychology; 41(3):310-27.

Owens JE, Menard M, Margaret Plews-Ogan M, Calhoun LG, Ardelt M. (2016). Stories of Growth and Wisdom: A Mixed-Methods Study of People Living Well With Pain. GLOBAL ADVANCES IN HEALTH AND MEDICINE; 5(1):16-28.

Pan TM, Mills SD, Fox RS, Baik SH, Harry KM, Roesch SC, \& Malcame VL. (2017). The Psychometric Properties of English and Spanish Versions of the Life Orientation TestRevised in Hispanic Americans. Joumal of psychopathology and behavioral assessment, 39(4), 657-668.

Park N, Park M, \& Peterson C. (2010). When is the search for meaning related to life satisfaction? Applied Psychology: Health and Well-Being, 2,1-13.

Peterson C, \& Seligman MEP. (2004). Introduction: Strengths of courage. In C. Peterson \& M. E. P. Seligman (Eds.), Character strengths and virtues: A handbook and classification (pp. 197-212). Oxford, England: Oxford University Press.

Peterson C. (2000). The future of optimism. American psychological; 55(1):44-55.

Pinquart M. (2002). Creating and maintaining purpose in life in old age: a meta-analysis. Ageing International, 27,90-114.

Poursardar N, Poursardar F, Panagandeh A, Sangari A, Abdi zarin S. (2013). The Effect of Optimism (Positive Thinking) on Mental Health and Life Satisfaction: A Psychological Model of WellBeing, Wise; 16(1):42-50. (in Persian)

Robitschek C, Anderson L. (2011). Personal growth initiative: Predicting depression, well-being, and functioning in college students. Poster presented at the annual convention of the American Psychological Association, Washington, DC.

Robitschek C, Ashton MW, Spering CC, Geiger N, Byers D, Schotts GC, et al. (2012).
Development and psychometric evaluation of the Personal Growth Initiative Scale-II. Journal of Counseling Psychology; 59:274-87.

Robitschek C, Keyes CLM, Keyes. (2009). Model of mental health with personal growth initiative as a parsimonious predictor. Joumal of Counseling Psychology; 56:321-9.

Robitschek C. (1998). Personal growth initiative: The construct and its measure. Measurement and Evaluation in Counseling and Development; 30:183-98.

Robitschek C. (2003). Validity of Personal Growth Initiative Scale scores with a Mexican American college student population. Journal of Counsel-ing Psychology; 50(4):496-502.

Schlegel RJ, Hicks JA, Amdt J, King LA. (2009). Thine own self: True self-concept accessibility and meaning in life. Joumal of Personality and Social Psychology; 96:473-90.

Seligman MA, Csikszent MH. (2000). Positive psychology: American Psychologist; 55(1): 514.

Shamsi A, Ghamarani A, Samadi M, Ahmadzadeh M. (2012). Validity and Reliability of Original Personality Scale,. Psychological Models and Methods;2(8):89-100. (in Persian)

Sharma SK, Garg P, Rastogi R. (2011). Personality as a Predictor of Personal Growth Initiative. The IUP Joumal of Organizational Behavior; 10(3):41-5.

Sharma SK, Rani R. (2014). Impact of Mental Health on Personal Growth Initiative (PGI) among University Postgraduates. Research on Humanities and Social Sciences; 4(3):134-47.

Shogren K, A Lopez SJ, Wehmeyer ML, Little TD \& Pressgrove CL. (2006). Therole of Positive Psychology constructs in predicting life satisfaction in adolescents with and without cognitive disabilities: Exploratory study. The Joumal of Positive Psychology, 1(1), 37-59.

Staudinger UM, Gluck J. (2011). Psychological Wisdom Research: Commonalities and Differences in a Growing Field. Annu Rev Psychol; 62:215-41.

Steger MF, Frazier P, Oishi S, \& Kaler M. (2006). The Meaning in Life Questionnaire: Assessing the 


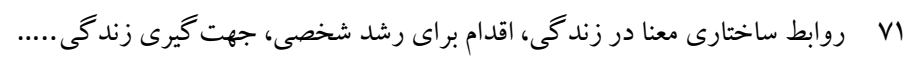

presence of and search for meaning in life. Journal of Counseling Psychology, 53, 80-93.

Steger MF, Kawabata Y, Shimai S, \& Otake K. (2008).

The meaningful life in Japan and the United States: Levels and correlates of meaning in life. Journal of Research in Personality, 42, 660 678. doi:10.1016/j.jp.2007.09.003

Stevic CR, Ward RM. (2008). Initiating personal growth: The role of recognition and life satisfaction on the development of college students. Social Indicators Research in Psychological Health; 89:523-34.

Theran SA. (2010). Authenticity with authority figures and peers: Girls' friendships, self-esteem, and depressive symptomatology. Joumal of Social and Personal Relationships; 27:519-34.

Vaingankar JA, Subramaniam M, Chong SA, Abdin E, Edelen MO, Picco L, et al. (2011). The positive mental health instrument: Development and validation of a culturally relevant scale in a multi-ethnic Asian population. Health and Quality of Life Outcomes; 9(92):1-18.

Weigold IK, Porfeli EJ, Weigold A. (2013). Examining tenets of personal growth initiative using the Personal Growth Initiative Scale-II. Psychological Assessment; 25(4):1396-403.

Wong PTP. (2012). Introduction. In P. T. P. Wong (Ed.), the human quest for meaning: theories, research and applications (2nd ed., pp. xxixxliv). New York: Routledge.

Wood AM, Linley PA, Maltby J, Baliousis M, \& Joseph S. (2008). The authentic personality: A theoretical and empirical conceptualization, and the development of the authenticity scale. Journal of Counseling Psychology, 55, 385399.

Yaniv I, Choshen-Hillel S. (2012). Exploiting the wisdom of others to make better decisions: suspending judgment reduces egocentrism and increases accuracy. $\mathrm{J}$ Behav Decis Making; 25:427-3. 